\title{
ASSESSMENT OF BUSINESS CUSTOMERS SATISFACTION WITH THE PRODUCTS AND SERVICE OF PNEVMOSTROIMASHINA, JSC, ON THE B2B MARKET
}

The paper is dedicated to development of a methodology for assessment of customer satisfaction with the products and services on the b2b market. The study of customer satisfaction is aimed at building strong and mutually beneficial supplier-customer relationship. The authors focus on the importance of customer satisfaction continuous monitoring intended for improvement of the company's market performance. The research based on the works by N. Kano, J.-J. Lamben, R. Carter, A. Parashuraman, V.A. Zeitaml, L. L. Berry and others, describes an algorithm study of consumers and offers a methodology to evaluate customer satisfaction with the industrial products.

Based on the analysis of the economic crisis effects on the machine-building industry, the authors determine the performance of "Pnevmostroimashina" JSC on the road and construction equipment market and illustrate an example of practical use of the customer satisfaction assessment technique in the company. At the end of the paper some recommendations for development of an efficient customer satisfaction measurement procedure are introduced.
The global financial crisis revealed weaknesses of the domestic machine-building industry and had a negative effect on the Russian industrial enterprises. Thus, a sharp decline in demand for road-construction equipment from operating organizations resulted in stockpiling of this type of equipment in the manufacturers' warehouses. The financial difficulties caused by resection in sales led to reduction and even suspension of many productions. In turn, this trend influenced drop in demand for components, and, as a consequence, stirred up financial instability of assembler-producers.

Understanding of the need for reorientation of marketing activities by the owners and managers of industrial enterprises is another specific feature of the crisis. The main emphasis is put now on improvement of compliance with discerning taste and specific requirements of a particular customer rather than on maximizing profits. Drucker P., the management guru, wrote: «There is only one legitimate justification for conducting business: creating a satisfied customer» [1].

In the post-crisis environment companies are oriented to the problem how to retain the existing cus- 
tomers, attract new clients and effectively interact with them at all stages of purchase: from producing in accordance with individual requirements to selling goods and providing after-sales service. This is one of the most challenging marketing issues. In case of $b 2 b$ markets, the mentioned problem can be solved by satisfaction level monitoring of the key customers.

Despite the fact that a lot of works by Russian and foreign authors are devoted to the aspects of customer relationships, many statistical methods for measurement of customer-supplier interaction efficiency were developed; but so far there is no effective tool for assessment of customer satisfaction with product quality and service level. The problem of measuring customer satisfaction is still not studied well.

\section{A theoretical background for customer satisfaction analysis}

There is a variety of methodological approaches to evaluation of customer satisfaction with consumer goods and industrial products. Different algorithms, methods and rating scales are proposed. Meanwhile, a few studies are devoted to development of a universal methodology for customer satisfaction assessment.

In the majority of methodological approaches respondents are required to evaluate products, services and business performance according to a number of criteria. Thus, in 1995 Carter R. advocated a comprehensive approach to supplier selection by a customer. This approach is known as "Carter's $10 \mathrm{Cs}$ for supplier selection" [2]:, namely: Competence: all staff, all the time requires evidence; Capacity: sufficient and flexible; Commitment: to quality quality systems; Control: control of the process; Cash: sufficient funds for the business; Cost: cost/ price relationships and total cost of ownership; Consistency: consistent production of goods or services; Culture: compatible with similar values; Clean: environmentally sound, conforming with legislative requirements; Communications: a supplier is fully integrated with information and communication technology.

One of the most popular approaches is the model of three levels of satisfaction by Kano N. (1980), in which customer satisfaction depends proportionally on a level and type of product quality [3]. Expected quality of goods is characterized by what might encourage or induce the purchase. Desired product quality implies that in case the product is improved, the satisfaction level will increase. Attracting or exciting quality of the product represents an unexpected level of service. In such cases, customers are agreeably surprised, delighted and even stunned.
Moreover, the exciting quality soon turns into the expected.

Lamben J.-J. offers an overall assessment procedure for measurement of a level of satisfaction or dissatisfaction [4]. It is based on the concept of multiattributive model and includes three stages: first, an average value of overall satisfaction with a product or service is calculated; second, an average value of satisfaction and importance for each characteristic is measured; finally, assessment of intention to repeat transaction is carried out. In order to determine the level of satisfaction for the most important characteristics, which impact the consumer choice, the ratio of satisfaction / importance is assessed.

The Gap model, developed in 1985-1991 by American researchers Parashuraman A., Zeitaml V.A., Berry L. L. offers to measure customer satisfaction with service by analyzing the gap between expectations and actual level of services rendered. Gap means excess of consumer expectations in the assessment of services received [5-6]. The Gap model allows understanding the process of rendering services in general, identifying a possible source of poor quality of the given services.

The Likert Scale, proposed by Likert R. in 1932, is a method of multi-factor assessment, in which respondents evaluate the criteria using the scale starting from one critical position through a neutral one, and to another critical position, such as "completely satisfied", "to some extent satisfied" etc. Each criterion has a rating scale. [7]. The given approach is simple but unreliable because it does not take into account the importance of criteria for customers when evaluating a company's performance. This makes it difficult to identify the scopes that require urgent improvement to a customer's perspective.

The study conducted by Mittal B. and Lassar V. M. shows that dissatisfaction guarantees unloyalty, while only total satisfaction provides loyalty [8]. Therefore, overall customer satisfaction is a significant factor in creating loyalty, which requires regular monitoring of consumer satisfaction dynamics.

In the literature, practical application of the above models is reflected more independently of each other, that substantially limits comprehensive understanding of a customer satisfaction level. Moreover, according to the majority of methods, a customer satisfaction level is evaluated only based on parameters of product quality or service level that is not enough for qualitative assessment of customer satisfaction and a detailed analysis of customer feedback. Combining different approaches allows conducting a more detailed analysis. 


\section{A methodical approach to measure customer satisfaction}

The authors' method is based on theoretical approaches by Lamben J.-J., Parashuraman A., Zeitaml V. A. and Berry L. L. As a research tool of the methodology a five-point Likert scale and the Gap model are used.

The authors suggest an organizational mechanism to conduct a research of customer satisfaction with industrial products. It includes several stages.

Stage 1. To set a survey goal, which may consist in identification of critical factors causing drop in product demand; definition of customers' expectations in order to maintain a leading position on the market; customer segmentation according to certain indicators, and so on.

Step 2. In cooperation with all the company's departments to elaborate a list of criteria, which are important for a customer as well as for a producer and evaluation of which allows achieving the research goal. Taking into account specific features of industrial products and customers' behavior regarding product selection and buying process, the authors suggested including two types of parameters in the questionnaire. The first group consists of the product quality parameters: compliance of a product's technical characteristics with the customers' requirements; adequacy of the product life span; packaging quality and reliability (ease of opening, warehousing, storage); warranty period. The second group includes service level parameters: supplier reliability and stability; supplier contract performance; delivery time; convenience of cooperation with the manufacturer's Sales department and/or its trade representative (calls frequency, accessibility, efficiency, professionalism); quality, adequacy and convenience of technical documentation; quality and speed of warranty service and repair; possibility of obtaining technical and design consulting (availability, frequency of complaints, sufficiency of consulting, efficiency, professionalism); frequency and quality of information on new product types.

Stage 3. To prepare a database of companies responding.

Stage 4. To work out a questionnaire: to formulate questions, chose a rating scale.

Stage 5. To send questionnaires to personal respondent companies by fax or e-mail. To keep track their routing in the responding companies.

Stage 6. To perform an analysis based on the questionnaire data collected, and to evaluate customer satisfaction with the product quality and service level.
In case of industrial customer analysis the authors suggest the respondents are divided into two groups: customers of primary and secondary markets. The former group includes manufacturing companies or OEM companies, which purchase industrial products for further use as components in their product manufacture, the latter consists of reselling companies.

The authors' method of industrial customer satisfaction assessment is presented in Table 1.

The authors introduced the formula for assessment of satisfaction with a service level and offered to measure overall customer satisfaction, which marks the customers' opinion about the products and services (S1). Previously, only product quality parameters were studied and calculated. The authors refined upon the methods by reducing the list of questions in the questionnaire; simplifying question wording; including open-ended questions; setting a rating scale. Moreover, the authors analyzed customer satisfaction in the context of product types; tracked satisfaction dynamics in all the surveyed companies and systematized the mechanism for data collection and processing.

The given technique is applied for Pnevmostroimashina, JSC. The changes in the assessment procedure introduced by the authors have improved the customer research model previously used at the enterprise. In accordance with the findings of the customer satisfaction research held in 2009, the authors provide some recommendation. First, it is recommended that the assessment technique was introduced in the companies of JSC Pnevmostroimashina distribution network in order to study end-users of the company's products. To increase involvement of the company's departments in achievement of the common goal to strengthen partnership with customers and gain profits, the authors offer to bring the research results to the management notice and use them in the work of all the departments. In order to increase respondents' motivation to fill in the questionnaires and to get customer feedback, it is recommended that a written notice on the activities developed and approved for execution on the basis of the questionnaires was sent to the customers.

\section{"Pnevmostoimashina" JSC performance in the machine-building industry}

JSC Pnevmostroimashina is the Russian leading manufacturer of hydraulics and Russia's and CIS countries' largest supplier of hydraulic components for domestic manufacturers of road construction equipment: excavators, loaders, rollers, cranes, graders, asphalt pavers, concrete mixers, as well as municipal machines and combine harvesters. 
Table 1

Method of industrial customer satisfaction assessment

\begin{tabular}{|c|c|c|}
\hline Indicator & Stage: formula & $\begin{array}{l}\text { Rating scale, maximum indicator } \\
\text { value }\end{array}$ \\
\hline \multicolumn{3}{|c|}{ 1. Analysis of the primary market customers (PM) } \\
\hline \multicolumn{3}{|c|}{ 1.1 Rating of criteria importance when selecting a supplier } \\
\hline $\begin{array}{l}I_{P M}-\text { importance } \\
\text { indicator for the } \\
\text { primary market } \\
\text { customers }\end{array}$ & \begin{tabular}{|}
$I_{P M}=\frac{\sum_{i=1}^{n} P}{n}(1)$, \\
$P-$ criterion, $n-$ number of respondents
\end{tabular} & $\begin{array}{l}\text { One-to-five scale is used, } 5-\text { very } \\
\text { important, } 1-\text { of no importance. } \\
\text { Maximum indicator value equals } \\
\text { to } 5 \text { points or } 100 \%\end{array}$ \\
\hline \multicolumn{3}{|c|}{ 1.2 Rating of product and service criteria satisfaction } \\
\hline $\begin{array}{l}S_{1}^{\prime}-\text { customer } \\
\text { satisfaction with the } \\
\text { product quality }(P Q)\end{array}$ & $\begin{array}{c}S_{1}^{\prime}=\frac{\left(\frac{\sum_{i=1}^{n} P_{P Q 1}}{n}+\ldots+\frac{\sum_{i=1}^{n} P_{P Q 4}}{n}\right)}{4} 100(2), \\
P_{P Q 1}, \ldots, P_{P Q 4}-\text { product quality criteria, } n-\text { number of respondents }\end{array}$ & $\begin{array}{l}\text { Scale of one to five is used, } 5- \\
\text { excellent, } 1-\text { poor. } \\
\text { Maximum indicator value equals } \\
\text { to } 5 \text { points or } 100 \%\end{array}$ \\
\hline $\begin{array}{l}S_{1}^{\prime \prime}-\text { customer } \\
\text { satisfaction with the } \\
\text { service level }(S L)\end{array}$ & $\begin{array}{c}S_{1}^{\prime \prime}=\frac{\left(\frac{\sum_{1}^{n} P_{S L 1}}{n}+\ldots+\frac{\sum_{1}^{n} P_{S L 8}}{n}\right)}{8} 100(3), \\
P_{S L 1}, \ldots, P_{S L 8}-\text { service level criteria, } n-\text { number of respondents }\end{array}$ & $\begin{array}{l}\text { Scale of one to five is used, } 5- \\
\text { excellent, } 1-\text { poor. } \\
\text { Maximum indicator value equals } \\
\text { to } 5 \text { points or } 100 \%\end{array}$ \\
\hline $\begin{array}{l}S_{1} \text { - customer } \\
\text { satisfaction with the } \\
\text { product quality and } \\
\text { service level }\end{array}$ & $S_{1}=\frac{\left(S_{1}^{\prime}+S_{1}^{\prime \prime}\right)}{2}$ & $\begin{array}{l}\text { Scale of one to five is used, } 5- \\
\text { excellent, } 1-\text { poor. } \\
\text { Maximum indicator value equals } \\
\text { to } 5 \text { points or } 100 \%\end{array}$ \\
\hline \multicolumn{3}{|c|}{ 1.3 Competitive supplier analysis } \\
\hline $\begin{array}{l}S_{2}-\text { indicator } \\
\text { reflecting customer } \\
\text { attitude to the } \\
\text { competitive } \\
\text { suppliers' products }\end{array}$ & $\begin{array}{l}\qquad S_{2}=\frac{\sum_{i=1}^{n}(A+B)}{n}(5) \\
\begin{array}{l}A-\text { a situation, when a customer buy the products from only one } \\
\text { supplier, } B-\text { a situation, when a customer buy the products from } \\
\text { several competing suppliers; } n-\text { number of respondents }\end{array}\end{array}$ & $\begin{array}{l}\text { B criterion equals to } 2 \text { points, } A \\
\text { criterion equals to } 1 \text { point. } \\
\text { Maximum indicator value equals } \\
\text { to } 2 \text { points or } 100 \%\end{array}$ \\
\hline \multicolumn{3}{|c|}{ 1.4 Defect analysis } \\
\hline $\begin{array}{l}S_{3}-\text { indicator } \\
\text { reflecting a return } \\
\text { quantity of products } \\
\text { over a warranty } \\
\text { period }\end{array}$ & $\begin{array}{l}\qquad S_{3}=\frac{\sum_{i=1}^{n} \frac{N_{B}}{V_{s}}}{n} 100(6) \\
N_{s}-\text { return quantity over a period; } V_{B}-\text { purchase quantity over a } \\
\text { period; } n-\text { number of respondents }\end{array}$ & $\begin{array}{l}\text { Each criterion value corresponds } \\
\text { to a certain number of points. } \\
\text { Maximum indicator value equals } \\
\text { to } 5 \text { points or } 100 \%\end{array}$ \\
\hline \multicolumn{3}{|c|}{ 1.5 Calculation of the primary market customers satisfaction } \\
\hline $\begin{array}{l}S_{P M}-\text { overall } \\
\text { satisfaction indicator } \\
\text { of the primary } \\
\text { market customers }\end{array}$ & $S_{P M}=S_{1}+S_{2}+S_{3}(7)$ & $\begin{array}{l}\text { Maximum indicator value equals } \\
\text { to } 5 \text { points or } 100 \%\end{array}$ \\
\hline \multicolumn{3}{|c|}{ 1.6 Gap analysis between customers' expectations and satisfaction } \\
\hline $\begin{array}{l}\text { The gap discrepancy } \\
\text { is calculated under } \\
\text { every criterion }\end{array}$ & $G_{P M}=I_{P M}-S_{P M}(8)$ & $\begin{array}{l}\text { To show the gaps between } \\
\text { customers' expectations and } \\
\text { satisfaction on a graph. }\end{array}$ \\
\hline \multicolumn{3}{|c|}{ 2. Analysis of the secondary market customers (SM) } \\
\hline \multicolumn{3}{|c|}{ 2.1-2.6 The identical analysis of the secondary market customers is conducted } \\
\hline \multicolumn{3}{|c|}{ 3. Analysis of the overall customer satisfaction indicator } \\
\hline \multicolumn{3}{|c|}{ 3.1 Calculation of the overall customer satisfaction indicator for the primary and secondary markets } \\
\hline $\begin{array}{l}S-\text { integrated } \\
\text { customer satisfaction } \\
\text { indicator }\end{array}$ & $\begin{array}{l}\qquad S=\frac{S_{P M}+S_{S M}}{2}(9) \\
S_{P M}-\text { overall satisfaction indicator of the primary market } \\
\text { customers; } \\
S_{S M}-\text { overall satisfaction indicator of the secondary market } \\
\text { customers }\end{array}$ & $\begin{array}{l}\text { Maximum indicator value equals } \\
\text { to } 12 \text { points or } 100 \%\end{array}$ \\
\hline & $\begin{array}{c}\text { measures aimed customer satisfaction growth; assigning people } \\
\text { setting deadlines }\end{array}$ & nsible fo \\
\hline
\end{tabular}




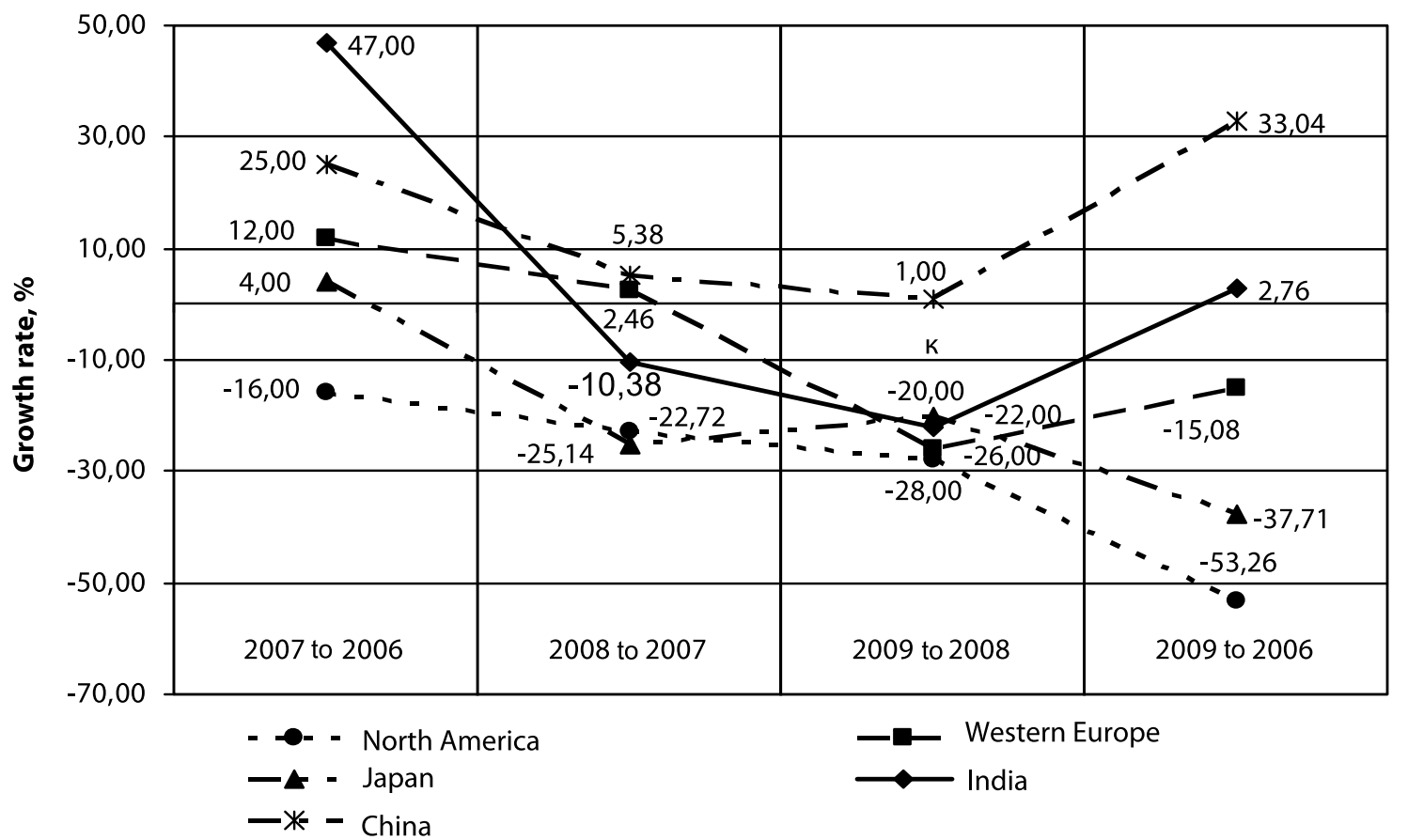

Fig. 1. Dynamics of demand for road-construction equipment in 2006-2009, \%.

Source: 1) The market for construction machinery: the peak is passed. Forecast for 2009: [web]. url: http://www.mashportal.ru/ machinery_russia-14921.aspx (access dated on: 17.05.2010); 2) At the bottom... the market for construction machinery. Results of 2009: [web]. url: http://www.prom-marketing.ru/articles/114-5201-machines.2009.html (access dated on: 17.05.2010).

In 2007, the company's share in the domestic market amounted to almost $80 \%$, in the global market it has $2.5 \%$ in the axial-piston hydraulics segment. One-fifth of the total sales are exported.

The company has widespread distribution and service networks in Russia and CIS countries: 5 trading houses, 9 distributors, 46 dealers; 15 sales representatives in CIS and non-CIS countries and 41 service centers. The products are exported to the Western and Eastern Europe, East Asia and Latin America.

According to the data of the Off-Highway Research consulting firm, amid the global financial crisis of 2008-2009 the Chinese, European, Indian, Japanese and North American markets saw a downward trend in demand for road-construction equipment that resulted in export reduction to these regions by $15 \%$ by JSC Pnevmostroimashina. Dynamics of demand for road-construction equipment in five major world markets is presented in Fig. 1.

According to data provided by the public organization "Russian Engineering Union", in 2009 production of tractor, agricultural, forestry, roadconstruction and municipal machinery decreased by $49.1 \%$ as a result of a sharp drop in demand due to financial insolvency of buyers, payment delay, increased inventory in stock, difficulties in obtaining loans to ensure continuous output [9]. Import reduced significantly (Fig. 2).

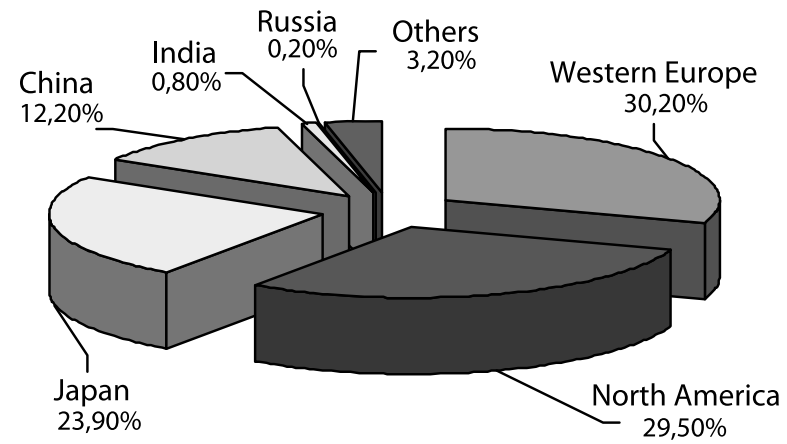

Fig. 2. Pattern of demand for road-construction equipment by the countries, \%

Source: Yellow Table: 50 world's largest manufacturers of construction machinery in 2009.: [web]. url: http://www.xn-80aaf4aa1aocn7h.net/articles/marketing/ id=9390 (access dated on: 17.05.2010)

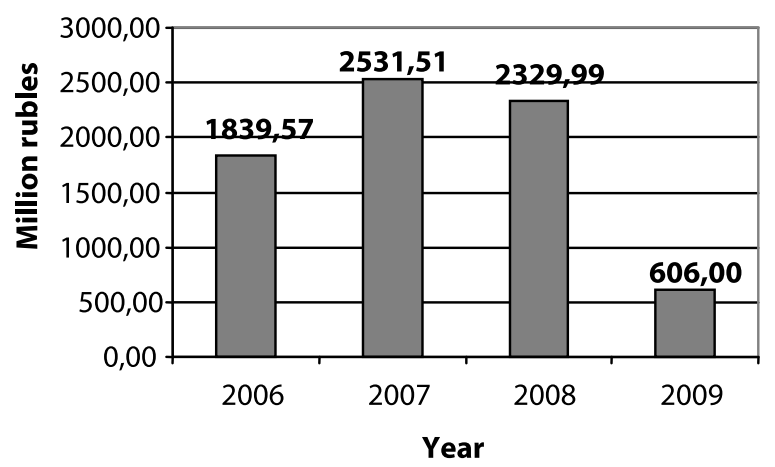

Fig. 3. Sales dynamics "Pnevmostroimashina" JSC in 20062009, million rubles 
Dynamics of road-construction equipment production by product type, ea

\begin{tabular}{|c|c|c|c|c|c|}
\hline \multirow{2}{*}{ Type of road-construction equipment } & \multicolumn{4}{|c|}{ Production output of road-construction equipment by years } & \multirow{2}{*}{$\begin{array}{c}\text { Growth rate } 2009 \\
\text { to } 2006, \%\end{array}$} \\
\hline & 2006 & 2007 & 2008 & 2009 & \\
\hline Truck cranes and manipulators & 4148 & 5451 & 5443 & 1459 & $-41,12$ \\
\hline Excavators & 2744 & 3806 & 3895 & 877 & $-61,18$ \\
\hline Graders & 1041 & 1269 & 1362 & 623 & $-34,35$ \\
\hline Loader & 1093 & 971 & 463 & 178 & $-65,17$ \\
\hline Concrete mixers & 2078 & 3080 & 2163 & 172 & $-71,04$ \\
\hline Road rollers & 451 & 548 & 639 & 88 & $-78,79$ \\
\hline Tower cranes & 418 & 531 & 466 & 35 & $-46,97$ \\
\hline Asphalt mixing plant & 58 & 94 & 102 & 28 & $-52,54$ \\
\hline Asphalt pavers & 66 & 103 & 142 & 25 & $\mathrm{n} / \mathrm{a}$ \\
\hline TOTAL & 12097 & 15853 & 14675 & 3485 & $-52,46$ \\
\hline
\end{tabular}

Source: compiled by the authors on the basis of data provided by "Stroydorm-UK" Ltd., "Stroydormash" Association

Influenced by the negative effects of the economic crisis, the purchasing power of domestic road-construction equipment producers, which are the target customers of JSC Pnevmostroimashina reduced significantly.

Table 2 shows the dynamics of the road-construction machinery production in Russia in 2006-2009.

Reduction in the output of the major road-construction equipment resulted in a five times drop of JSC Pnevmostroimashina production (Fig. 3).

To overcome the crisis and ensure competitiveness of domestic machinery producers on the Russian and global marketplace, it is required to develop and implement an integrated approach, combining development and introduction of modern technologies, to supply plants with high-technology equipment of the world leading producers, to con- duct personnel training for establishing so-called "smart plants". Machine-building ensures production saturation with new technical means and technologies and it is, ultimately, the main source of innovation development and further growth of the country [10].

The post-crisis industrial Russian market is characterized by the intensifying competition with the world leading machine-building companies, which establish their assembly plants in Russia. Under these circumstances domestic industrial enterprises pay more attention to customer research, development of individual technical solutions to meet the most demanding requirements. Development and implementation of an effective methodology for measurement of customer satisfaction will facilitate the work with customers and help to identify strong

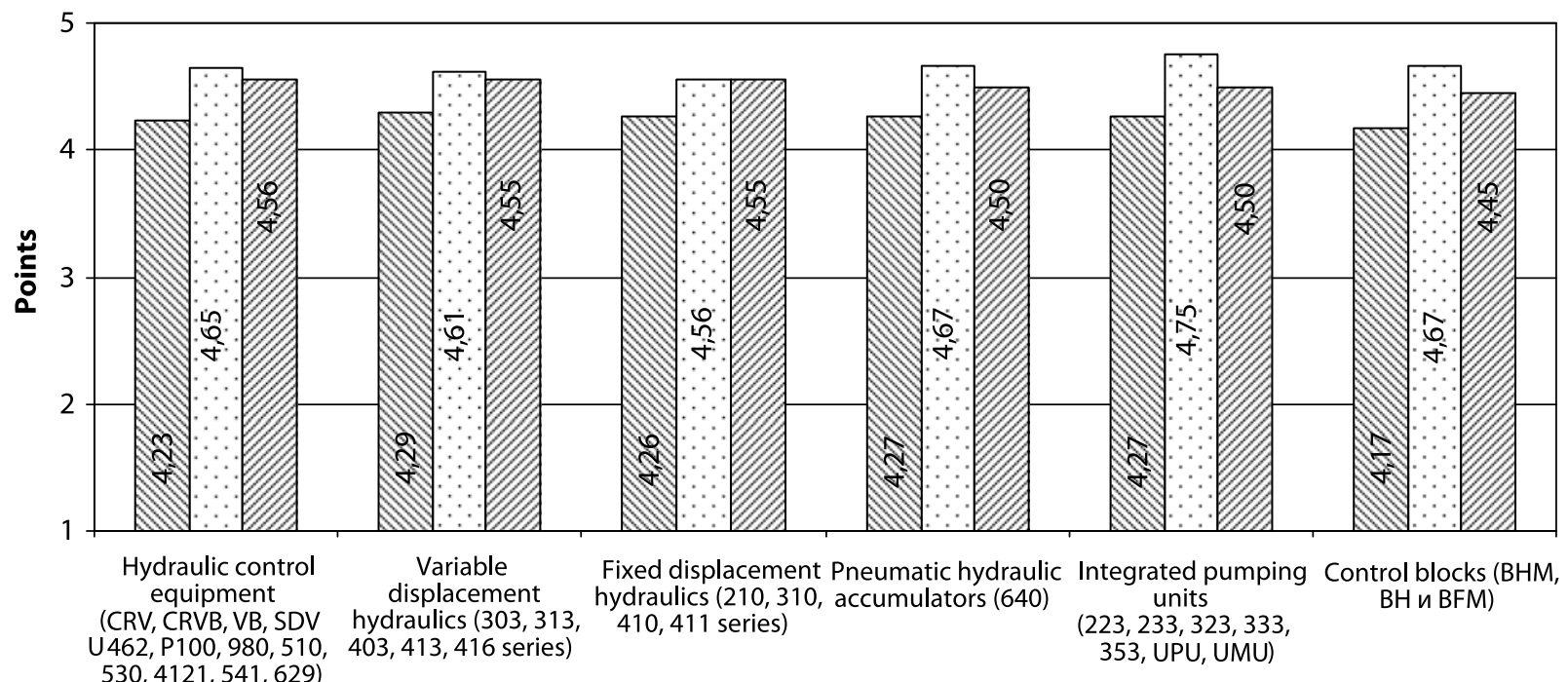

Product type

S December 2007

December 2008

December 2009

Fig. 4. Dynamics of primary market customer satisfaction with product quality by product type, points 
Quality, adequacy and convenience of technical documentation

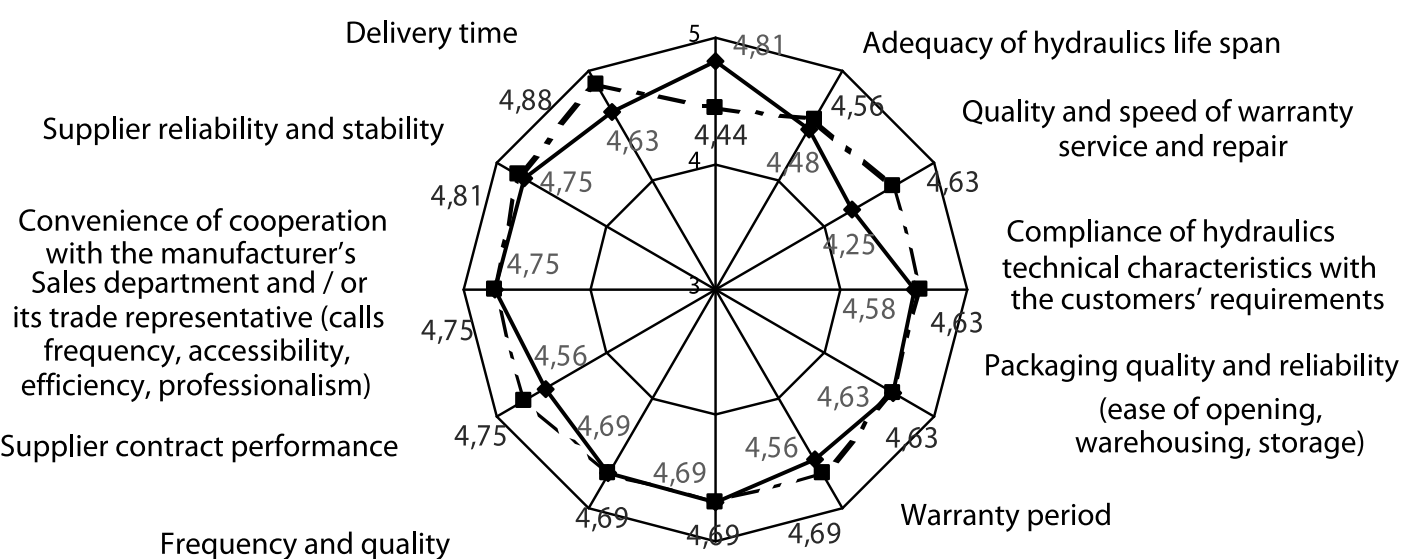
of information on new hydraulics types

Possibility of obtaining technical and design consultation (availability, frequency of complaints, sufficiency of consultations, efficiency, professionalism)
$\longrightarrow$ Satisfaction
-E - Importance

Fig. 5. Gap analysis between expectations and satisfaction of the primary market customers, points

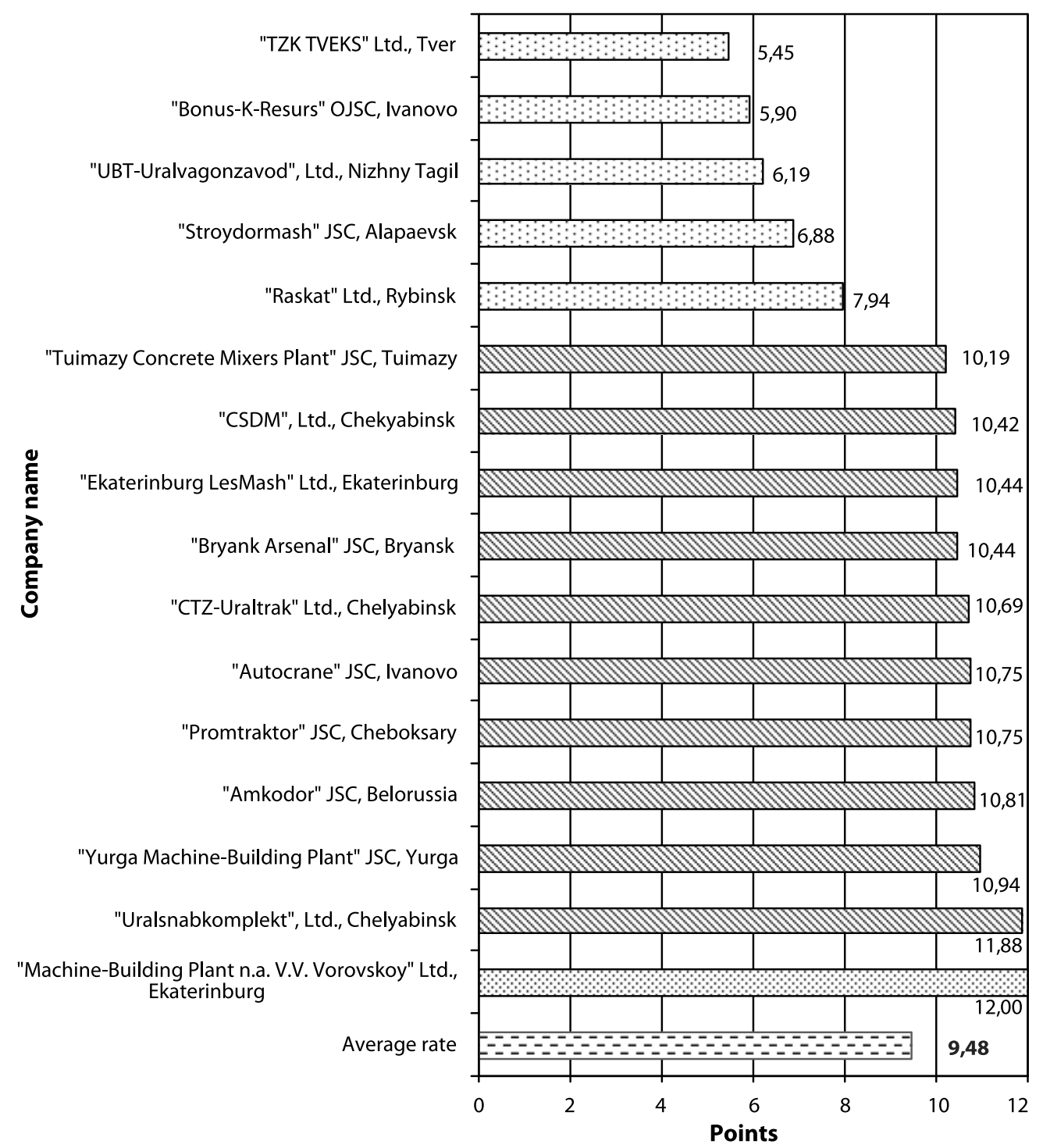

Fig. 6. Customer satisfaction levels on the primary market in December 2009, points 


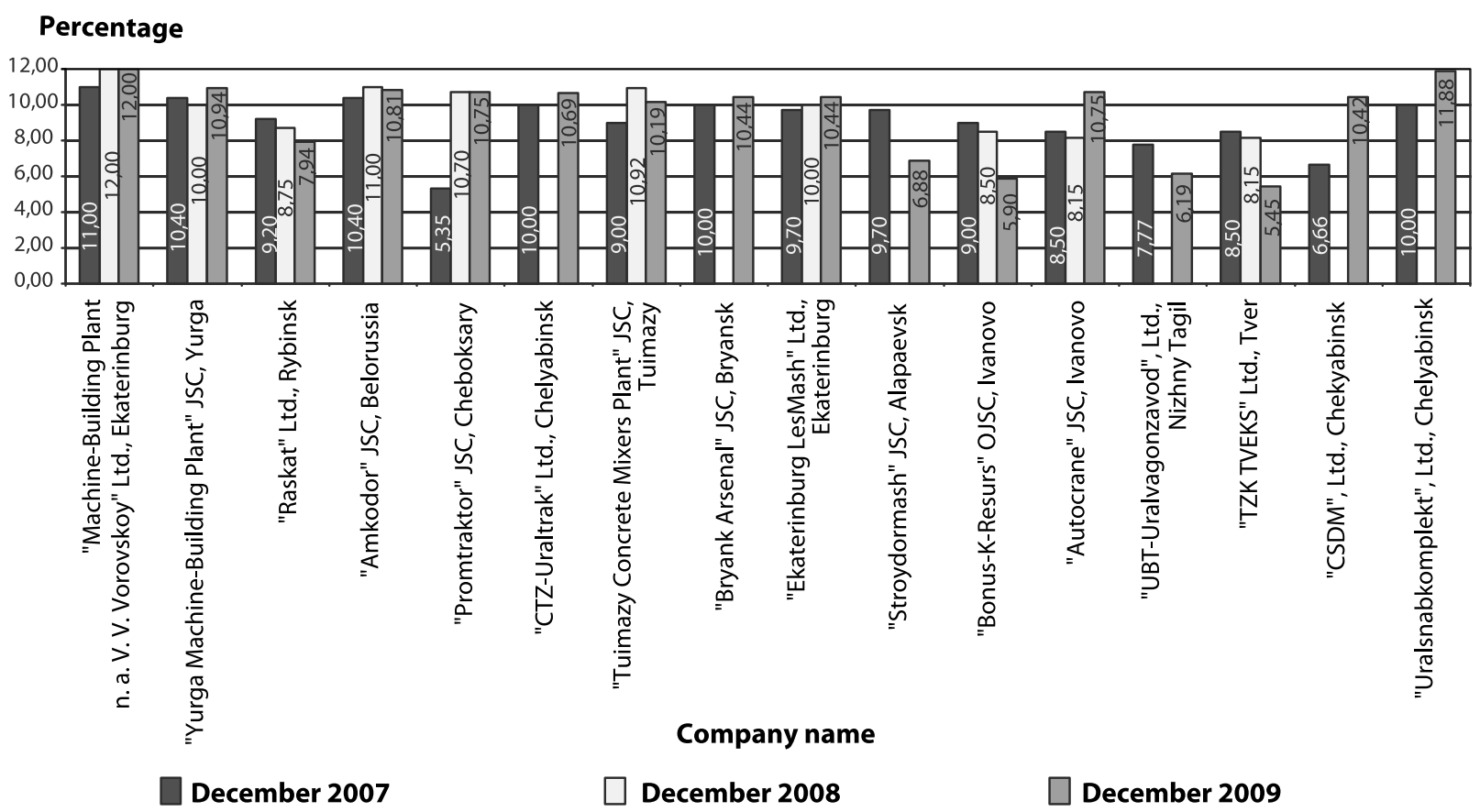

Fig. 7. Dynamics of customer satisfaction on the primary market, points

and weak points of an enterprise, which require improvement to enhance customer loyalty and increase market share.

\section{Customer satisfaction assessment at Pnevmostroimashina, JSC}

Road-construction equipment producers or primary market companies, as well as the distribution network entities or secondary market companies, are the respondents in the customer satisfaction survey held by JSC Pnevmostroimashina". The customer satisfaction analysis is conducted twice a year (in July and December) and consists of two parts: the analysis of primary market companies and the analysis of secondary market companies.

The authors have made calculations to assess primary market customer satisfaction with the product quality of JSC Pnevmostroimashina, and the analysis of values over the past three years that are presented in Figure 4.

Based on the results of the primary market customer analysis, the criteria are ranked in order of importance for the respondents and the gap analysis between customers' expectations and satisfaction is conducted (Fig. 5).

An analysis of the gap between customers' expectations and satisfaction discovered the fact that the high satisfaction criteria have high importance rating for the respondents. At the same time, the criteria requiring improvement due to the fact that their importance ratings exceed the satisfaction level, are identified.
Calculation of the average customer satisfaction indicator shows that $70 \%$ of primary market customers rate their satisfaction with products and services above average as shown in Figure 6.

The analysis of changes in the satisfaction level with product quality and service level by customers of the primary market for the last 3 years is shown in Figure 7.

In the 1st and 2nd half of 2009 the average customer satisfaction index on the primary market amounted to 9.41 points $(78.38 \%$ ) and 9.48 points (78.98\%), respectively. The overall customer satisfaction index on the primary and secondary markets equals to 10.32 points $(85.96 \%)$. The dynamics of the integrated consumer satisfaction indicator is shown in Figure 8.

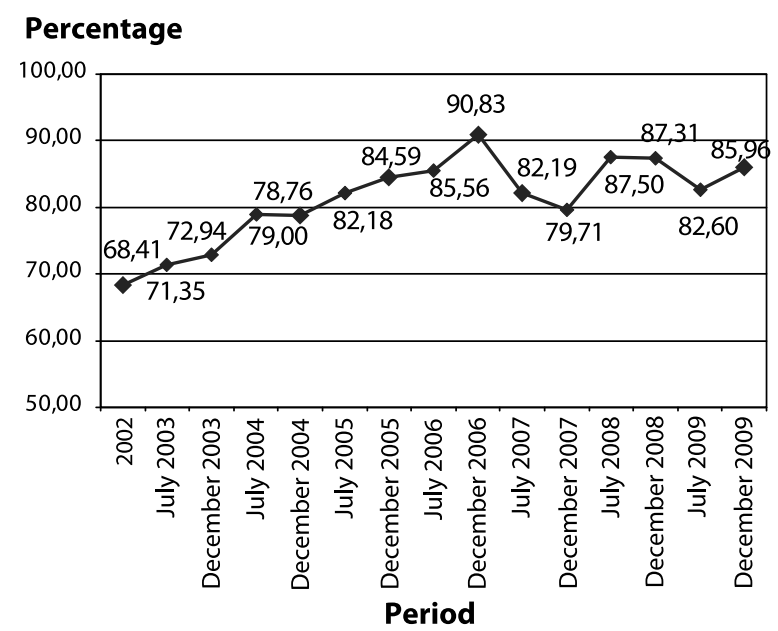

Fig. 8. Dynamics of the integrated customer satisfaction indicator in 2002-2009 
Thus, heightened attention is paid to the needs and expectations of customers to meet growing customer expectations. Customer satisfaction becomes one of the most efficient marketing tools, capable of measuring efficiency of a company and predicting the way a company's market share may change depending on a current level of customer satisfaction.

When selecting ways to increase company's competitiveness, customer satisfaction, as well as customer expectations, product quality and service parameters are to be estimated.

Investigation of consumer satisfaction regularly executed by the specialists of the marketing department, allows upgrading technical characteristics of a product during its production and improving quality of service, thereby enhancing the company's competitive position on the industrial market.

\section{References}

1. Tracy, B. (2004). Victory! Translation from English by E. A. Bakusheva. Mn.: «Poppuri» JSC, 236 p.

2. Carter, R. (1995). The Seven Cs of Effective Supplier Evaluation. Purchasing and Supply Chain Management.

3. Kano, N., Nobuhiku, S., Fumio, T., Shinichi, T. (1984). Attractive quality and must-be quality. Journal of the Japanese Society for Quality Control, 14 (2).

4. Lamben, J.-J. (1996). Strategic Marketing. European perspective. Translation from French. Saint-Petersburg: Nauka. 589 p.
5. Zeitaml, V. A. A., Berry, L. L., Parasuraman, A. (1988). Communication and Control Processes in the Delivery of Service Quality. Journal of Marketing, Vol. 52.

6. Parasuraman, A., Berry, L. L., Zeitaml, V. A. (1985). Conceptual Model of Service Quality and Its Implication for Future Research. Journal of Marketing, Vol. 49.

7. Predvoditeleva, M. D., Balaeva, O. N. (2005). Approaches to service quality management: focus on the consumer. Management in Russia and abroad, 2. Moscow. 144 p. pp. 90-97.

8. Mittal, B., Lassar, W. M. (1998). Why do customers switch? The dynamics of satisfaction versus loyalty. Journal of Services Marketing, Vol. 12,

9. Monthly informational and analytical bulletin. Public Organization "Russian Engineering Union", Committee on the tractor, agricultural, forestry, road-construction and municipal machinery. Moscow. January 2010, Vol. 1 (18). 130 p. p.3.

10. Klimov, G. (2008). On the state and machinery in Russia. Intelligent production, 2 (5).

\section{U.D.C. 338.4}

Keywords: customer satisfaction, customer expectation, b2b market, industrial products, business customer, method of customer satisfaction assessment, service level, product quality, questionnaire, respondent, market research, criterion importance, customer satisfaction index, customer loyalty, OEM's market, secondary market. 